\title{
Sunk Costs and Mortgage Default
}

\author{
Richard K. Green* \\ Eric Rosenblatt\# \\ Vincent Yao\#
}

February 4, 2010

\begin{abstract}
.
In this paper, we estimate default hazard functions that include standard variables along with borrowers sunk cost: i.e., down payment at loan origination. After testing large numbers of specifications, we find that after controlling for mark-to-market loan-to-value, initial combined loan to value remains an important predictor of default. We also find, contrary to Guiso, Sapienze and Zingales (2009), that there is not a specific point at which one observes a discontinuous default probability, but that it is rather that default is smooth in mark-to-market LTV.
\end{abstract}

*University of Southern California, 650 Childs Way, Los Angeles, CA 90089.

\#Fannie Mae, 3900 Wisconsin Ave, Washington, DC 20016.

Draft. Do not distribute or cite without consent of authors. The opinions of the authors are their own and do not necessarily represent their institutions. 


\section{Sunk Costs and Mortgage Default}

\section{Richard K. Green, Eric Rosenblatt and Vincent Yao}

\section{Introduction}

The current mortgage crisis, along with its consequent macroeconomic crisis, has produced a large number of surprises and/or puzzles. But it also provides us with some clues as to why households and firms may have deviated from behaviors predicted by traditional models of economic behavior.

For us, recent events have allowed us to focus on how we might better understand mortgage default. In a world where transactions costs are minimal, borrowers should be "ruthless" about default: when the value of their house falls below the value of their mortgage (inclusive of the value of prepayment options), they should default on their loan and repurchase their house at the lower price. Kau and Keenan (1993 and 1999) and Foster and Van Order (1994 and 1985) were among the first to treat mortgage default as a put option with the mortgage balance being the strike price: the borrower puts the house back to the lender once the option is in the money.

But mortgage default does contain transaction costs. Some of them are straightforward: it costs money to move, and the point at which the house price falls below the mortgage balance is not the point at which the option is net in the money. But if moving were the only transactions cost, we would expect to see a threshold at which everyone defaulted. The fact is that we do not see such a threshold: it is a long established stylized fact that the hazard of the default is increasing in contemporaneous loan-to-value, but the relationship is smooth.

Part of the reason may be that default produces consequences for the ability to obtain credit or (possibly) to rent an apartment. Therefore households have to take into account the marginal benefit from default (i.e., the amount of debt relieved) relative to the marginal cost. One could imagine that such a calculation is highly heterogeneous. Indeed, Deng, Quigley and van Order (2001) showed that unobserved heterogeneity is a pervasive feature of borrower behavior. It is also possible that housing market heterogeneity influences default decisions. 
When a household is underwater with respect to its mortgage, it holds a call option; the ability to "buy-back" the house when its value is greater than the mortgage balance. Because volatility creates option value (about which we shall say more below), the call option embedded in an underwater mortgage is higher in high volatility places than it is in low volatility places.

Beyond all of this, it is quite striking how many people decide not to default even when the chances are that the cost of default is less than the benefits, and when the call option is worth nearly zero. Specifically, we find that loans can have loan-to-value ratios in excess of 240 percent, and yet continue to perform. Our suspicion is that people who continue to make payments on these loans either (1) do not fully understand what is happening in their housing markets; (2) feel a strong sense of responsibility toward meeting a "moral" obligation; and/or (3) feel that they would lose the cash equity they put into their house if they chose to default. Those falling into the last category suffer from "nominal loss aversion," a characteristic discussed in Kahneman and Tversky's (1979) work on prospect theory. Genesove and Mayer (2001) showed how nominal loss aversion affects seller behavior in sort real estate markets.

In this paper, we use down-payment size as an explanatory variable for mortgage default hazard, conditioned on loan-to-value ratios that vary across time because of changes in housing markets. If households with initial higher initial down-payments are less prone to default, it could mean that down-payment is a proxy for commitment, or that those who put high downpayments on their houses are more likely to be motivated by nominal loss aversion./

We also use measures of local house price volatility as an explanatory variable for default hazard. In the presence of foreclosure induced transactions costs, the put option will be greater in areas with higher house price volatility, and therefore we would expect high house price volatility to predict lower defaults.

Our paper is different from Kelly's (2008) recent work on source of down-payment and default, because we have a more comprehensive set of data and a richer set of explanatory variables. It is different from Guiso, Sapienza and Zingales (2009) work on strategic default, because it observes mortgage performance rather than rely on survey data. Its results contrast with Oliver Wyman, who maintain that borrowers are highly strategic when confronted with the decision to default. 
For the remainder of this paper, we will perform a literature review, discuss the theory of mortgage default, present our data, describe our empirical model, and present results.

\section{Literature}

We discuss briefly three strands of literature: the literature on mortgage default, the literature on prospect theory, and how it implies that initial loan-to-value might influence mortgage default, and the recent literature on strategic default.

\section{Default}

The literature on the determinants of mortgage default (as well as corporate development of default models) has been evolving for at least 25 years. Foster and Van Order (1984 and 1985) were among the first to model default as a put option. When a homeowner has a mortgage, and can extinguish or all of the obligation by putting a house back to the lender, she has a put option as well as equity in the house. The put option's value is a function of the drift and volatility of house prices: it is more valuable when house prices are more likely to fall, and more valuable when house prices are more volatile, because under both circumstances, the chance that the house will be worth less than the mortgage, and therefore in the money, is greater. The Foster and Van Order papers used house price volatility as a covariate for predicting default, and found that it was a significant and important predictor of default.

Kau and Keenan (1993 and 1999) show that even the absence of transactions costs, borrowers will not necessarily default immediately when the option is in the money. They derive the well known result that under risk neutrality, the value of a mortgage $M$ satisfies:

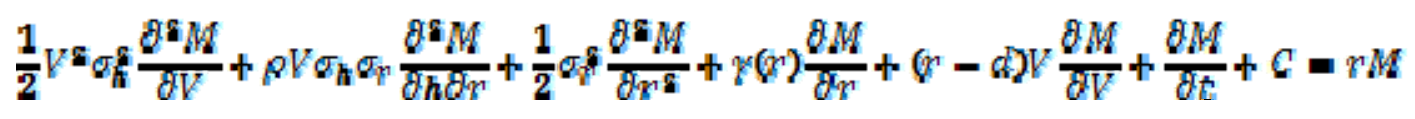

Where $\mathrm{M}$, the mortgage, is valued based on its coupon, $\mathrm{C}$, the spot interest rate $\mathrm{r}$, the value of the house, $\mathrm{V}$, the age of the mortgage, $\mathrm{t}$, and the time to maturity, $\mathrm{T}$. Let $\mathrm{d}$ be the imputed rental rate of the house. In the absence of frictions (i.e., costs of default beyond loss of the house), the optimal default strategy at time $\mathrm{t}$ is a function of the value of the house, $\mathrm{V}_{\mathrm{t}}$. Optimal default takes place when $\mathrm{V}_{\mathrm{t}}=\mathrm{V}_{\mathrm{t}}{ }^{*}$. Borrowers choose $\mathrm{V}_{\mathrm{t}}{ }^{*}$ such that the value of the mortgage is Confidential - Internal Distribution 
minimized, subject to the condition that the value of the mortgage balance is equal to the value of the house. The value of the mortgage balance is less than the present value of the remaining payments, because the mortgage contains a prepayment option as well as a default option.

Quigley and Van Order (1995) illustrate the optimal default strategy when interest rates are constant. The curve $\mathrm{AB}$ in figure one is the highest curve that satisfies the relationship between house prices and mortgage values represented in equation 1 while assuring that the mortgage value is less than the value of a riskless mortgage. This creates a tangency point which determines $\mathrm{V}_{\mathrm{t}}{ }^{*}$. Note that value of the house is less than (not equal to) the mortgage balance at the optimal point of default.

But the model has another important implication - that once house values pass below some threshold point, other issues, such as original loan-to-value ratio, should not affect mortgage behavior.

In a later paper, Deng Quigley and Van Order (2001) make two further contributions: they show that default models are best modeled in a competing risk framework, where default competes with prepayment. We will discuss the econometric specification of this model below. They also hypothesize that LTV is endogenous - that those who have asymmetric information that a particular house might lose value will take on higher LTVs than those who do not.

\section{Prospect Theory}

In a recent review article, DellaVigna (2009) describes Kahneman and Tversky's prospect theory:

Kahneman and Tversky (1979), in the second most cited article in economics since 1970 (Kim, Morse, and Zingales, 2006), propose a reference-dependent model of preferences that, unlike the standard model, can fit most of the experimental evidence on lottery choice. According to prospect theory, subjects evaluate a lottery (y, p; z, $1-p)$ as follows: $\pi(p) v(y-r)+\pi(1-p) v(z-r)$. Prospect theory is characterized by: (i)

Reference Dependence. The value function $v$ is defined over differences from a reference 
point $r$, instead of over the overall wealth; (ii) Loss Aversion. The value function $\mathrm{v}(\mathrm{x}$ ) has a kink at the reference point and is steeper for losses $(x<0)$ than for gains $(x>0)$; (iii) Diminishing Sensitivity. The value function $\mathrm{v}$ is concave over gains and convex over losses, reflecting diminishing sensitivity to outcomes further from the reference point; (iv) Probability weighting. The decision-maker transforms the probabilities with a probability-weighting function $\pi(\mathrm{p})$ that overweights small probabilities and underweights large probabilities.

Empirical findings consistent with prospect theory include Gensove and Mayer (2001) and List (2003 2004) for the housing market and Benartzi and Thaler (1995), Barberis, Huang, and Santos (2001) for the stock market. Odean (1998) found a "disposition effect," whereby sellers are more likely to sell their winners than their losers, even when tax considerations should tilt sellers to liquidating losers.

This paper continues in that tradition. While mortgage default theory does not precisely predict how far under water borrowers need be before they default, it does suggest that past some point, down payment at origination should be irrelevant to the determination of default . A down payment may be viewed as a reference; those who put a large down payment on a house may view themselves as having "more to lose" when they default than those who do not do so. Consequently, if borrowers have nominal loss aversion, those who finance their houses with large down payment may be less likely to default, conditional on mark-to-market loan to value ratio, than those who use small downpayments.

\section{Strategic Default}

Some recent papers have examined strategic default and the relationship between initial down payment and default. Kelly (2008) shows that recent work on source of down-payment and default, because we have a more comprehensive set of data and a richer set of explanatory variables. 
Guiso, Sapienza and Zingales (2009) use survey data to study American households' propensity to default when the value of their mortgage exceeds the value of their house even if they can afford to pay their mortgage (strategic default). They find that people who find it "immoral" to default are 77 percent less likely to do so than those who do not. While

the focus of the study is different from ours, and contains the limitation of using survey data to gage attitudes, it does look at a non-financial angle to mortgage default, and finds that such considerations matter when households make default decisions.

Oliver Wyman (2009) sorted through loan files and argued that the United States had more than one half million strategic defaults (i.e., defaults by borrowers who were capable of repaying their loans but found themselves with negative home equity) in 2008.

\section{Data}

The data used in this paper comes from three sources. First, we begin with a large proprietary mortgage database, containing approximately a quarter of all national mortgage transactions over the period from 2005 through 2008. The originations before 2005 are not included because few of these homeowners have negative equity, owing to both home price appreciation and amortization. Figure 1 shows that the home price level in 2009Q2, based on Loan Performance's HPI, is similar to that in 2004Q2 in nominal terms, and similar to that in 2002Q3 when adjusted for inflation. Borrowers who bought their houses in the peak of housing bubble, under the most relaxed underwriting standard, have suffered the most from home price decline.

From this mortgage data, we can identify all the original loan information and subsequent payment activity in each quarter until the loan is voluntarily prepaid, foreclosed, or still active as of 2009Q3. We randomly selected a sample of mortgages that financed owner-occupied home purchases from 2005 through 2008. The sample is further limited to single family 1-unit houses and fixed rate mortgages with 30-year amortization terms. There are 694,952 unique loan records that contain the following variables: credit score (FICO), combined loan to value ratio (CLTV), age and monthly income of borrower, origination date, and whether the loan is originated by a broker, correspondent, or retail channel. We also know the current unpaid principal balance in each quarter and the current status of the mortgage (prepaid or default) along with the exact 
liquidation date. The default and prepayment rates over this set of loans are $1.6 \%$ and $23.6 \%$ respectively. With proprietary zip-level home price indices, we are able to construct accurate mark-to-market CLTV (MCLTV) quarter by quarter. There are 6,154,364 records in the dataset and the average duration of loans is 9.47 quarters or about 2.5 years.

We also obtained MSA level unemployment rates for each quarter and each geographical area from the Bureau of Labor Statistics; we follow mortgage rates using the Freddie Mac Primary Mortgage Market Survey, as plotted in Figure 2. For each observation, we compute the difference in the market interest rate and the coupon rate at origination: this gives us a measure of the value of the call (refinance) option The variables used in the analysis are explained in Table 1 and their descriptive statistics are reported in Table 2. These are all prime conventional conforming borrowers, so their average FICO score is high at 719; average monthly income is also high at $\$ 6,900$. The average age of the borrowers in our sample is 40 . In this period, the sample is dominated by wholesale channels, with $23 \%$ and $33 \%$ of loans originated by brokers and correspondents respectively. With home prices declining from the peak in 2006 to 2009Q2, the average MCLTV is a little higher than the original CLTV, rising to $90.6 \%$ from $86.1 \%$. It suggests that homeowners' equity has shrunk even as there has been amortization. The distribution of duration, based on loan level data, is reported in Figure 3 by loan status. Without controlling for economic conditions, default peaks at 6-9 quarters after origination and prepayment peaks about 2 quarters earlier. The fast prepayment speeds reflect an environment in which interest rates are falling.

Raw statistics on CLTV and MCLTV, reported in Table 3, provide a snapshot of both original loan profiles and the impact of home price changes over the past 4 years. In the loan activity table, $33 \%$ of activity records have original CLTV $>95 \% .1$ About $37 \%(12.3 \% / 33 \%)$ of these borrowers have MCLTVs that remained flat $((95,100])$. The MCLTVs of the other $63 \%$ have well exceeded $100 \%$; i.e., most of these homeowners who began with an LTV of 95 percent or higher have negative equity. Although borrowers with lower original LTV are less likely to have negative equity, none of CLTV categories are immune to negative equity. Overall, about $17 \%$ of loans-have negative equity. Figure 4 plots the default and prepayment rates by initial

\footnotetext{
${ }^{1}$ This overestimates the share of high CLTV loans (31\%) in the loan-level data because that these loans tend to have longer durations.
}

Confidential - Internal Distribution 
down payment and current LTV. For each similar MCLTV, default rate increases in higher CLTV; for each similar CLTV, default rate increases in higher MCLTV. Prepayment relationships are less straightforward and unambiguous. For each similar CLTV, prepayment rate decreases in higher MCLTV. However, for each similar MCLTV, prepayment rate is indifferent to change in CLTV. This implies that the ability to refinance is influenced by owners' mark-tomarket equity —a sensible finding.

\section{Regression Models}

Default and prepayment are options available to homeowners at each period. They decide whether to exercise either of the options, provided that they have perfect information on the current value of mortgages and economic conditions. Due to the nature of competing risks between prepayment and default, only the duration associated with the type that terminates first is observed. Following Van den Berg (2001), the competing risk model or multivariate mixed proportional hazard (MMPH) defines two hazard equations as

$$
\begin{aligned}
& \theta_{1}(\mathrm{t} \mid \mathrm{x}, \mathrm{V})=\lambda_{1}(\mathrm{t}) \times \exp \left(\mathrm{x}^{\prime} \beta_{1}\right) \times \mathrm{V}_{1} \\
& \theta_{2}(\mathrm{t} \mid \mathrm{x}, \mathrm{V})=\lambda_{2}(\mathrm{t}) \times \exp \left(\mathrm{x}^{\prime} \beta_{2}\right) \times \mathrm{V}_{2}
\end{aligned}
$$

where durations $(\mathrm{T} 1, \mathrm{~T} 2) \mid(\mathrm{x}, \mathrm{V})$ are assumed independent, so that a dependence of the durations given $\mathrm{x}$ is modeled by way of their unobserved determinants V1 and V2 being

dependent. $\theta(t)$ is the hazard conditional on survival up to time $t$ and $\lambda(t)$ is the baseline hazard. We include three time-varying factors in $\mathrm{x}$ : MCLTV, change in mortgage rate and change in MSA-level unemployment rate since mortgage origination. Change in mortgage rate is used to measure the value of call option for homeowner while MCLTV is used to measure the value put option (Deng, Quigley and Van Order, 2000). The unemployment rate is a proxy for other "trigger events".

Table 4 reports maximum likelihood estimates of the parameters of models of competing risks of mortgage default and prepayment, and the estimated baseline hazards of competing risks are plotted in Figure 5. The model tests the effect of sunk costs in mortgage risks, in addition to current equity. The missing bucket of each variable is the reference value with coefficient 0 or hazard ratio 1. For instance, $\mathrm{MCTLV}<=80$ and $\mathrm{CLTV}<=80$; age $<=25$; retail loan; FICO $<620$; 
income $<\$ 2,000$; etc are reference buckets. Loans with FICOS below 620 are seven times more likely to default that loans with FICOs above 740. Older homeowners are also more likely to default.

None of these variables, however, explain much prepayment behavior. The default risk of high income households is not much different from that of low income households, however, high income earners are 2.4 times more likely to prepay their mortgages. Mortgage rate change measures whether the value of mortgage is "in the money," and the magnitude of the incentive to refinance. Prepayments increases as rates decrease, while defaults increase with mortgage rates, at least in part because the reduction in the value of the prepayment options reduces the difference between the nominal balance of the loan and the value of the loan net of options. The negative coefficient on unemployment rate change is not consistent with the anticipated effect of trigger events, and surprises us.

Estimated effects of MCLTV by CLTV, after controlling for other risk factors, are reported in Table 4(B) and also plotted in Figures 6(A) and 6(B). They confirm that sunk costs are as important as current negative equity in predicting default risk, but not in predicting prepayment risk. Except for a few isolated cells, default risks increase with CLTV for a given MCLTV bucket and increases with MCLTV for a given CLTV bucket. Thus sunk costs are an important mitigator of default risk. Comparison of change in default probabilities along CLTV and those along MCLTV (up to 100) suggests that incremental risks due to initial down payment and mark-to-market measure are of similar scale. For instance, for starting values of MCLTV $=90$ and CLTV=80, default hazard increases from 1.08 to 1.65 when CLTV moves up to 100 (holding MCLTV constant) and it increases from 1.08 to 1.68 when MCLTV moves up to 100 (holding CLTV constant). There is a consistent tradeoff between MCLTV and CLTV producing the same default hazard, so that one can draw an "iso-default" boundary (Table 4(B)). Along MCLTV spectrum, the slope of default risk is steep when MCLTV reaches 90 or 95 and then follows a straight line afterwards. Therefore, there is no apparent negative equity trigger (i.e., 110), as found in Guiso et al (2009). Un like the case of default, for prepayment risk, MCLTV is certainly more important than initial equity. This is consistent with the idea that nominal loss aversion can influence behavior-refinanced loans do not recognize losses, while default loans do. 
As robustness checks, we also estimated three competing risk models based on different restrictive samples. Table 5 presents results based on subsamples restricted to more liquidityconstrained borrowers, measured by CLTV $>95$, and those borrowers likely to be underwater, measured by MCLTV $>95$. Their coefficients are normalized to the first cell in Table 4(B) for comparison. In both cases, the change in hazard ratio is less steep for default risks and steeper for prepayment risks. However, the difference is small.

Tables 6 and reports statistics for three distinct states: California and Florida that have experienced steep and persistent home price declines in the past 2 years, while Texas has experienced only a mild decline. While the peak to current (2009Q3) decline for CA and FL is nearly $-50 \%$, TX almost breaks even for the same period. From Table 6 , loans originated in CA have higher FICO but lower CLTV, compared to other two.

Because house prices declined so sharply in California and Florida they have much greater increases in mark-to-market LTV from origination to termination relative to Texas; in California and Florida, the increase is around 30\%. Among those who defaulted, loan-to-values increased by 57 percent in California and 43 percent in Florida.

MCLTV in all three states had a statistically significant impact on the probability of default, and the impact generally rises in MCLTV. In Texas, however, the number of loans with very high LTVs is quite small. Generally speaking, if borrowers in Texas has an initial down payment of ten percent of more, they were not underwater. The fact that some borrowers defaulted despite having seemingly positive equity in their houses may likely reflects that fact that we can only know prices at small levels of geography, rather than at the individual household level.

Our results across the three states, however, give us some comfort that initial CLTV's effect on default is not working through a self-selection channel. Specifically, while CLTV is significant at the ten percent level and important in Florida and California, it is not so in Texasin fact, in Texas, default probabilities are decreasing in CLTV after controlling for MCLTV (Table 7). If borrowers used low down payment as a signal of default expectations, we should see that manifest itself more in a place where price movements were relatively small, such as Texas, because price movements will not overcome the idiosyncratic tendencies of borrowers. 
Rather, it seems to take a very large shock for borrowers to sort themselves based on initial CLTV. This likely reflects that borrowers behavior is based on financial capacity, prospect theory, or most likely, both. It is also interesting that coefficients for Florida and California are different from each other and for the nations as a whole. The comparison reinforces thats some portion of default risks unexplained by measured borrower's characteristics. As before, CLTV, or sunk costs, do not influence prepayment behavior (Table 8).

Finally, we look at the impact of vintage on LTV after controlling for measured characteristics. Returning to Table 2, we find, not surprisingly that 2006 and 2007 vintages have the highest MCLTV at termination. Such loans had higher CLTV at origination and were originated at the peak of housing bubble. This is also when underwriting standards were the most relaxed. Most Alt-A and high LTV (>97\%) loans were originated in these two years. Table 9 reports default coefficients from competing risk models by vintage year to isolate possible changes in underwriting standards, data quality, and economic environment. Except for 2008 vintages, loans with CLTV $>95 \%$ perform significantly worse than others, but the comparison among lower CLTVs varies across years. For 2005 vintage loans, default risks are similar to loans in the $80-90$ and $90-95$ buckets, but loans with CLTVs of less than $80 \%$ perform significantly better than the rest. In 2007, performance of CLTVs in the 90-95 bucket is similar to those in the $95+$ bucket.

\section{Conclusion}

In this paper, we have examined the impact of initial loan-to-value ratio, or sunk cost, on the probability of mortgage default for prime mortgages. We have found that borrowers with large initial down payments are in general far less likely to default, even when they are as far below water as those with smaller initial down payments.

These results are consistent with prospect theory; they also may reflect the fact that borrowers with high down payments are in a better position to weather economic downturns, may be less subject to trigger events, and therefore less likely to default. Given that initial down payment is not a statistically significant predictor of default in Texas, however, we think it unlikely that self selection is driving the relationship between CLTV and default probability. Specifically, if endogenous behavior were the driver behind the relationship between CLTV and 
default, we would expect it to manifest itself in places where house price movements did not swamp idiosyncratic borrower characteristics.

Finally these results are not consistent with the strategic default hypothesis put forward in Oliver Wyman (2009). If borrowers were strategic and ruthless, initial down payment should have no impact on borrower behavior. Our evidence shows that it does.

\section{References}

Barberis, Nicholas, Ming Huang, and Tano Santos. 2001. "Prospect Theory and Asset Prices", Quarterly Journal of Economics, 116(1): 1-53.

Benartzi, Shlomo and Richard H. Thaler. 1995. "Myopic Loss Aversion and the EquityPremium Puzzle.” Quarterly Journal of Economics 100, 73-92.

DellaVigna Stefano 2009 Psychology and Economics: Evidence from The Field, Journal of Economic Literature, June 2009, Vol. 47, pp. 315-372

Deng, Yongheng, John M. Quigley and Robert Van Order, 2000. "Mortgage Terminations, Heterogeneity and the Exercise of Mortgage Options," Econometrica, Econometric Society, vol. $68(2)$, pages $275-308$

Foster, Chester and Robert Van Order 1985 FHA Terminations: A Prelude to Rational Mortgage Pricing. Journal of the American Real Estate and Urban Economics Association Volume 13, Issue 3: pp. 273-291

Foster, Chester and Robert Van Order 1984 An Option-Based Model of Mortgage Default. Housing Finance Review, 3(4): pp. 351-372

Genesove, David and Christopher Mayer. 2001 Loss Aversion and Seller Behavior: Evidence from the Housing Market, Quarterly Journal of Economics, 116(4), 1233 1260.

Guiso, Luigi, Paola Sapienza and Luigi Zingales (2009) Moral and Social Constraints to Strategic Default on Mortgages, NBER Working Paper 15145.

Kau, J.B., D.C. Keenan and T Kim (1993) Transactions Costs, Suboptimal Termination and Default Probabilities, Journal of the American Real Estate and Urban Economics Association, 24(3) 279-999.

Kau, J.B. and D.C. Keenan (1999) Patterns of Rational Default, University of Georgia Working Paper. 
Kahneman, Daniel, and Amos Tversky. 1979. "Prospect Theory: An Analysis of Decision under Risk" Econometrica, 47(2): 263-292.

Kelly, Austin, 2008. "Skin in the Game: Zero down payment mortgage default," MPRA Paper 4318, University Library of Munich, Germany

Kim, E.H., Adair Morse and Luigi Zingales, 2006 What has matted in Economics since 1970. Journal of Economic Perspectives, 20(4) 189-202.

List, John A. 2003. "Does Market Experience Eliminate Market Anomalies?” Quarterly Journal of Economics, 118(1): 41-71.

List, John A. 2004. "Neoclassical Theory Versus Prospect Theory: Evidence from the Marketplace," Econometrica, 72(2): 615-625.

Odean, Terrance. 1998. “Are Investors Reluctant to Realize Their Losses?” Journal of Finance, 53(5): 1775-1798.

Oliver Wyman 2009. Press release on strategic default.

Quigley, John M \& Van Order, Robert, 1995. "Explicit Tests of Contingent Claims Models of Mortgage Default," The Journal of Real Estate Finance and Economics, Springer, vol. 11(2), pages 99-117

Van den Berg, G.J. 2001. Duration models: Specification, identification, and multiple durations. in J.J. Heckman and E. Leamer, editors, Handbook of Econometrics, Volume V North Holland, Amsterdam. 


\section{Figure 1}

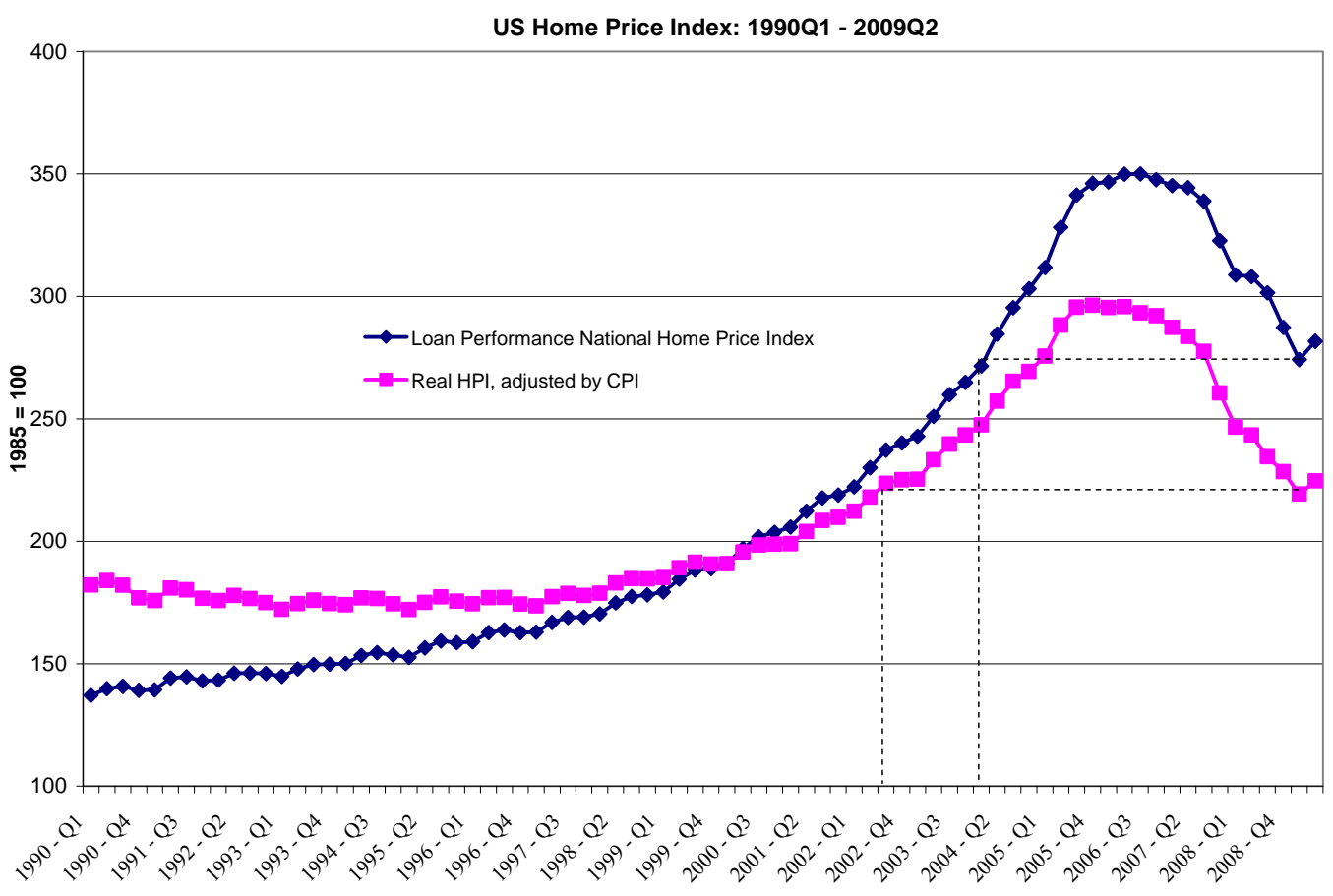

Confidential - Internal Distribution 
Figure 2

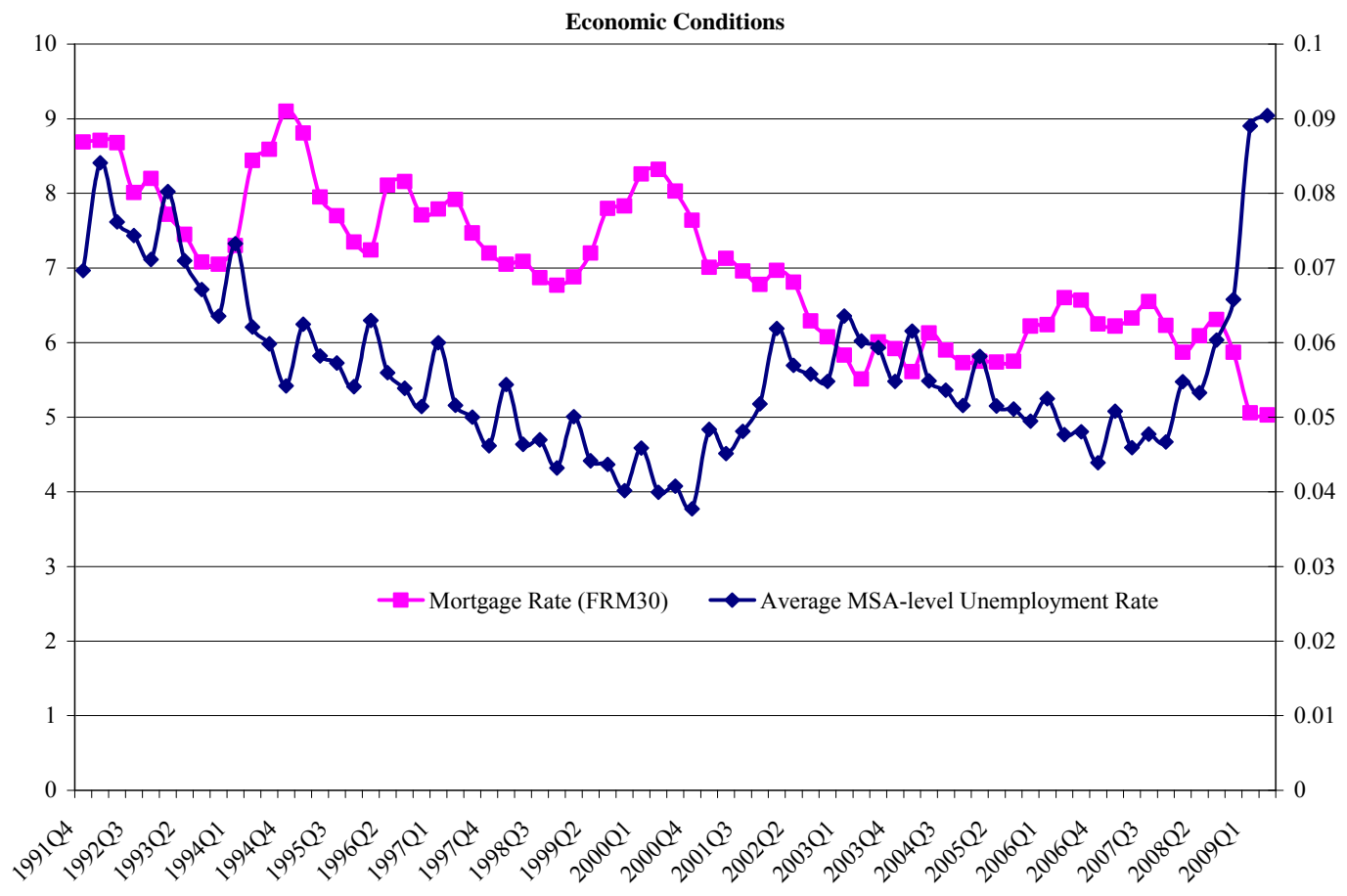

Confidential - Internal Distribution 
Figure 3

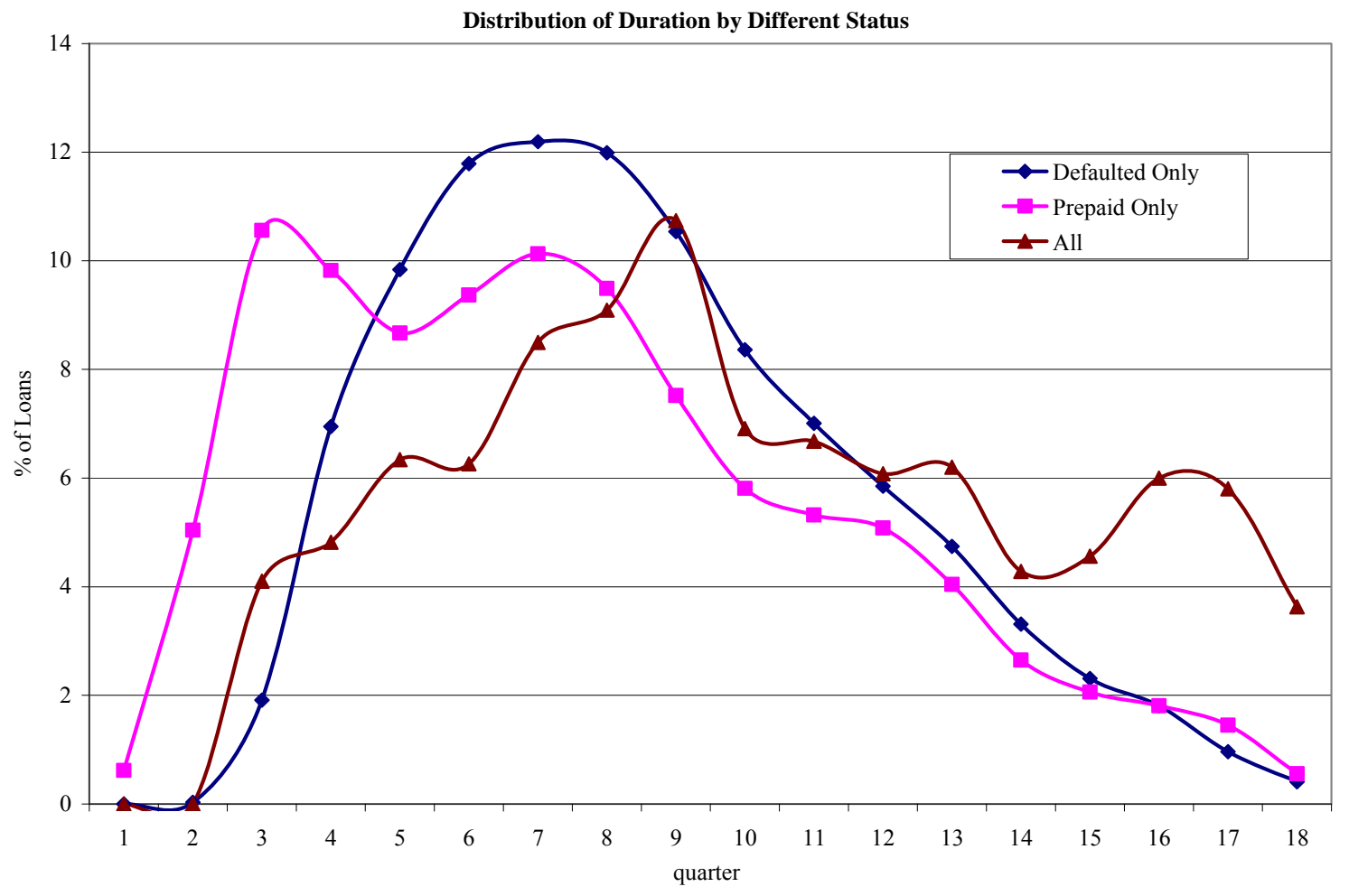

Confidential - Internal Distribution 
Figure 4 Raw Statistics
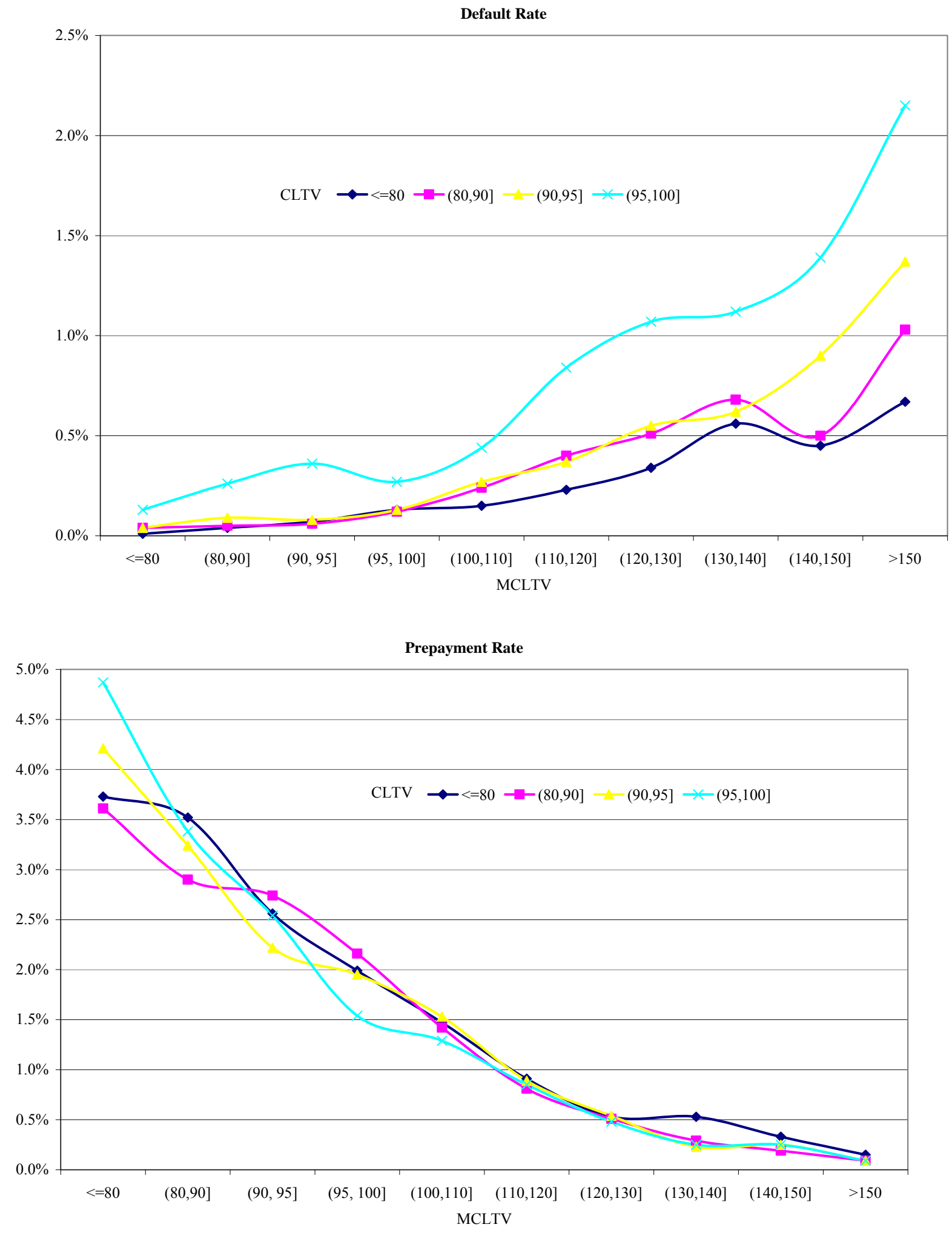

Confidential - Internal Distribution 
Figure 5

Estimated Baseline Hazard Rates of Default and Prepayment

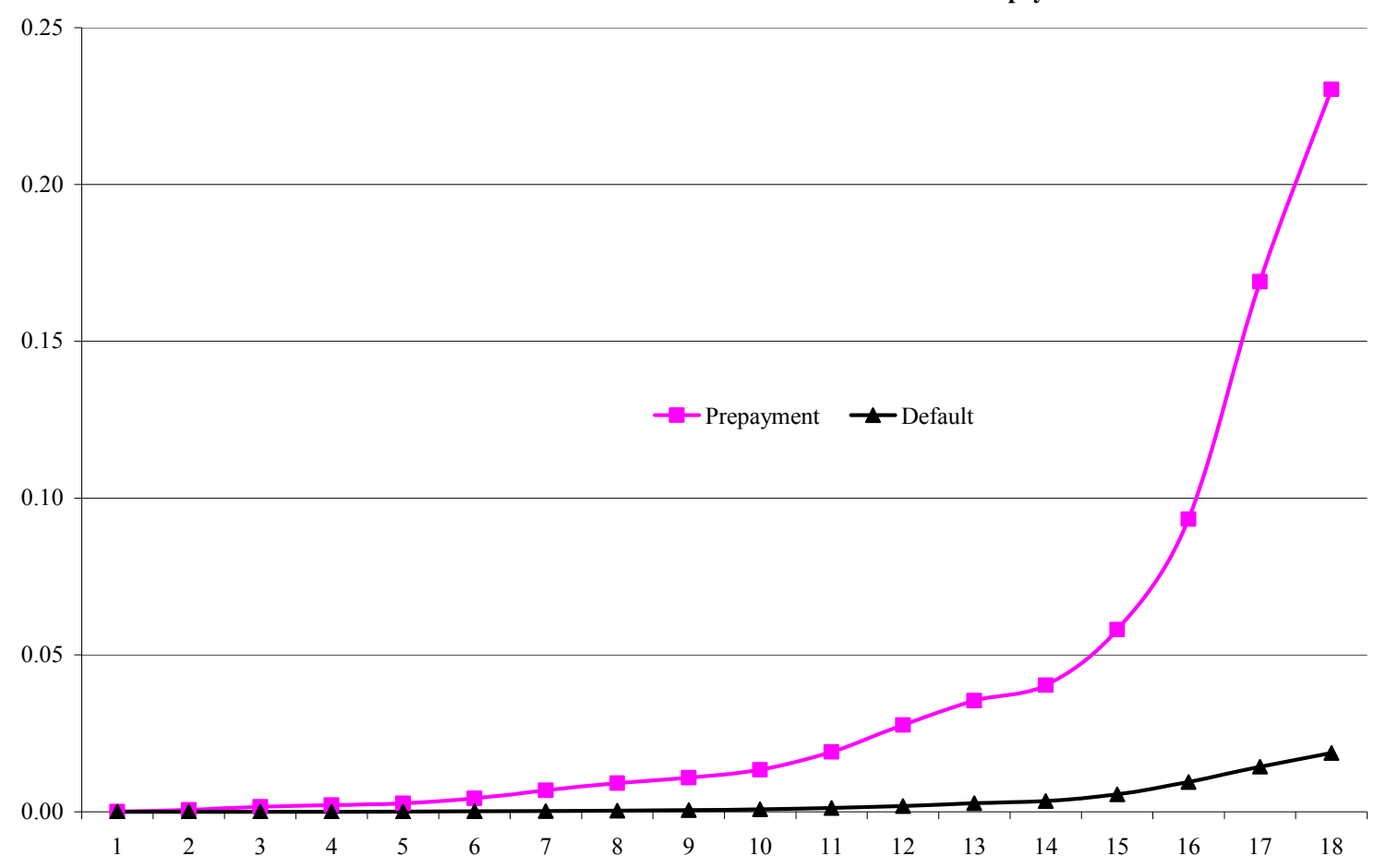

Confidential - Internal Distribution 


\section{Figure 6}

(A)

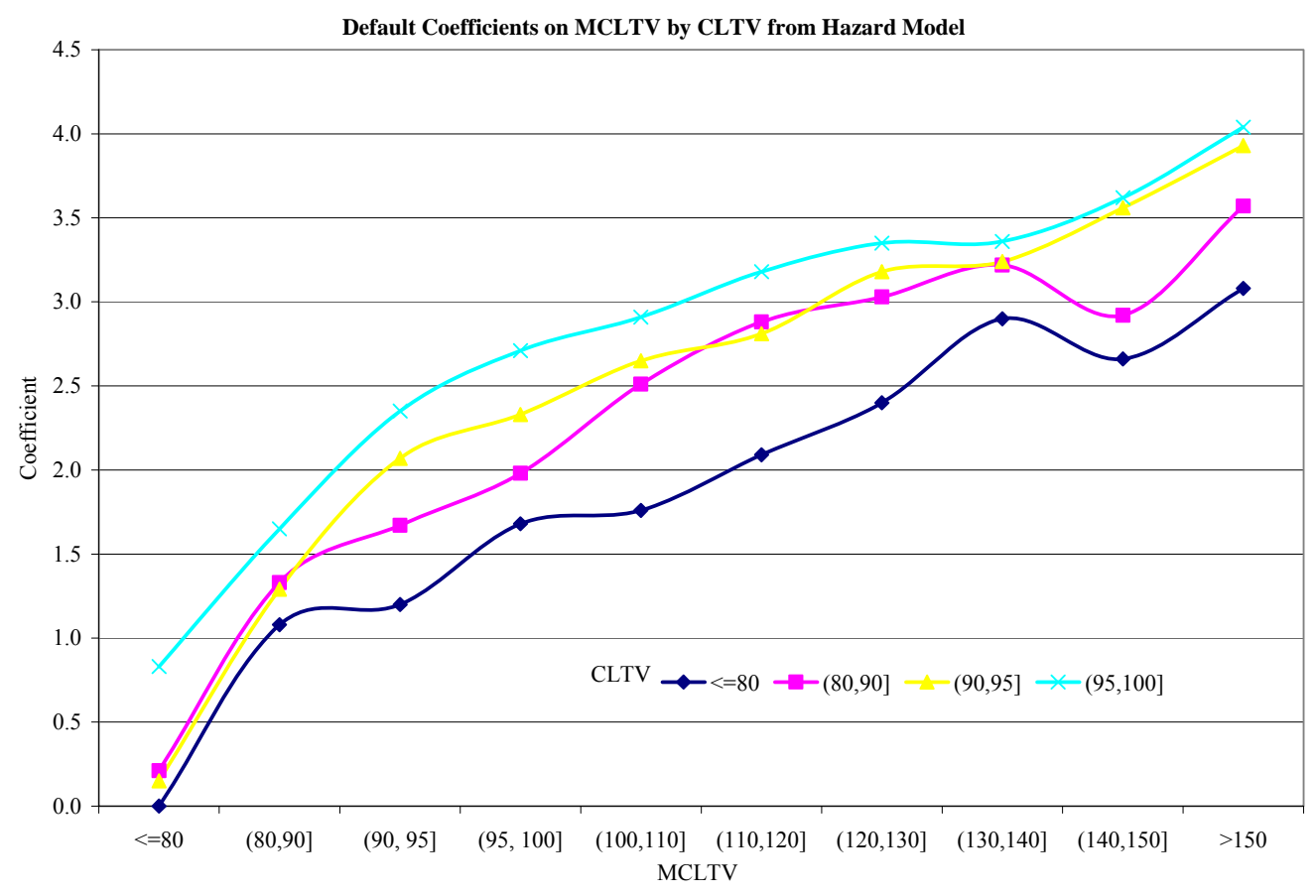

(B)

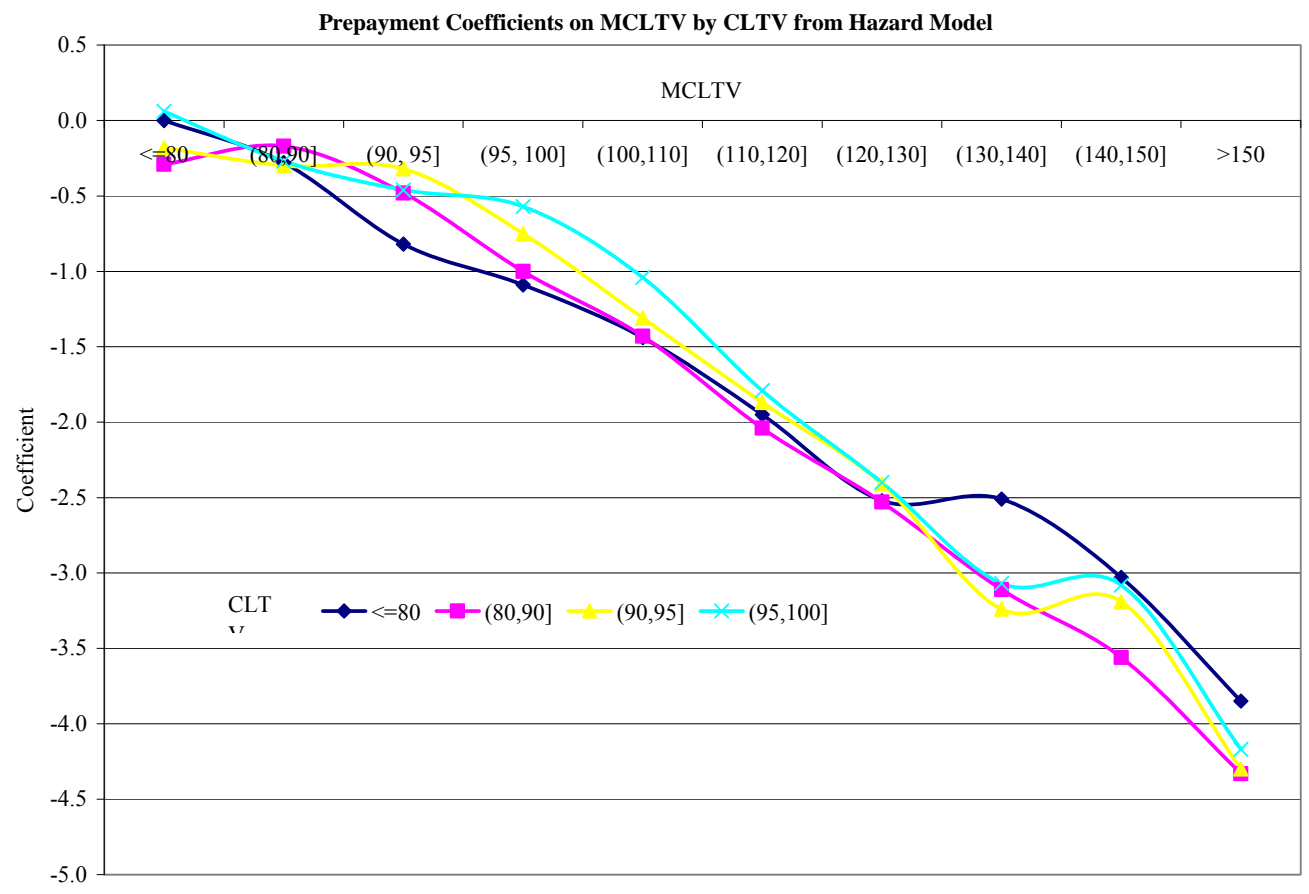

Confidential - Internal Distribution 


\section{Figure 7}
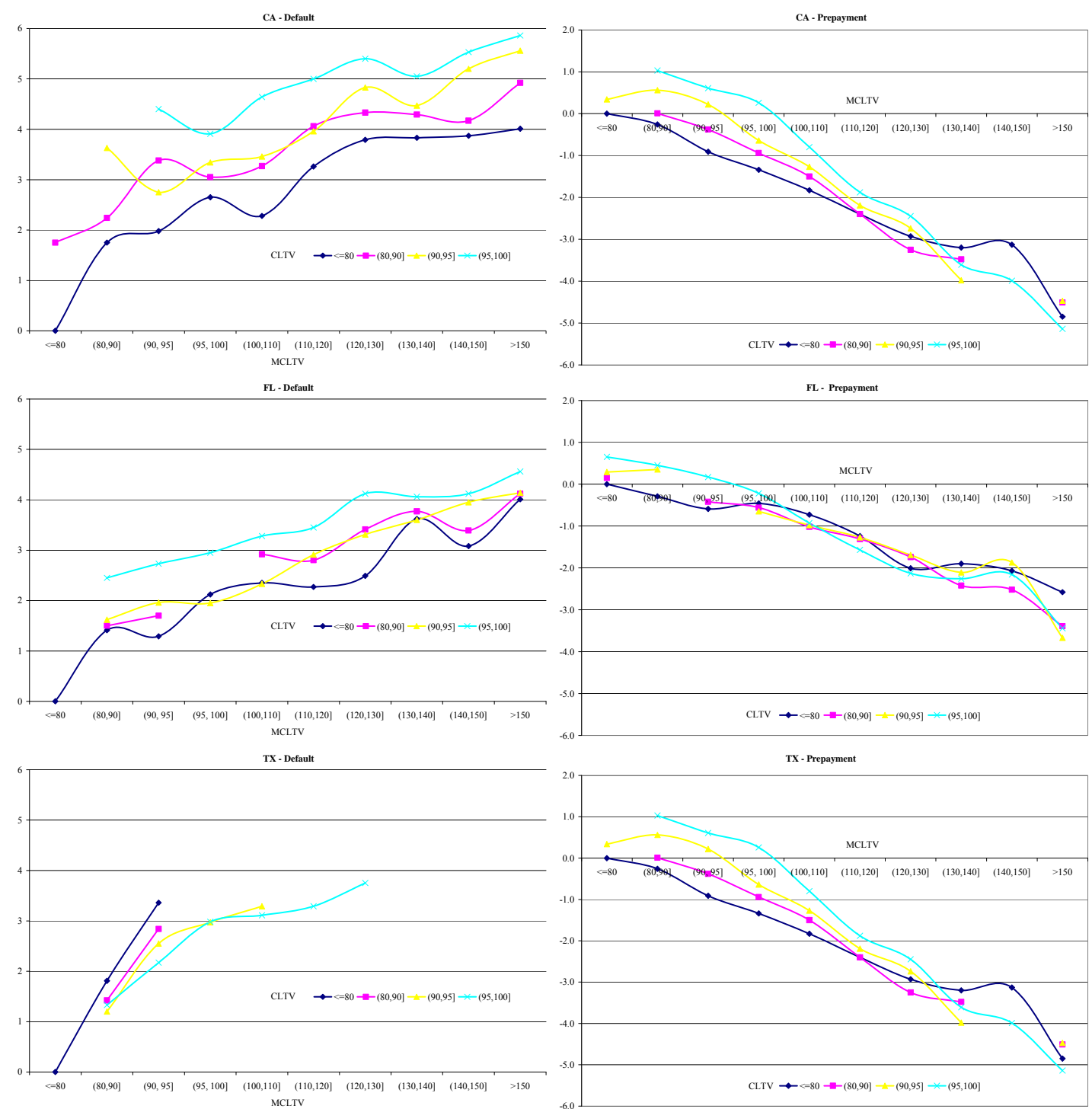

Note: only significant coefficients are plotted. 


\section{Table 1}

\section{Variable List}

\begin{tabular}{ll}
\hline Origination Variables \\
\begin{tabular}{ll} 
duration & Duration, in quarters, from origination to last payment date. For defaults, it's from origination to liquidation date. \\
default & 1 if default; 0 otherwise. \\
prepay & 1 if loan is voluntarily prepaid; 0 otherwise. \\
cltv & combined loan to value ratio. \\
broker & 1 if the loan is originated by a broker; 0 otherwise. \\
correspondent & 1 if the loan is originated by a correspondent; 0 otherwise. \\
fico & Credit score. \\
age & Age of the primary borrower. \\
income & Total monthly income. \\
y2005 & 1 if loan is originated in 2005; 0 otherwise. \\
y2006 & 1 if loan is originated in 2006; 0 otherwise. \\
y2007 & 1 if loan is originated in 2007; 0 otherwise. \\
y2008 & 1 if loan is originated in 2008; 0 otherwise. \\
obs & 694,952 \\
\hline Time-varying Variables (by payment history) \\
\hline msaemp_ch & Change in MSA-level unemployment rate from origination. Source: BLS. \\
rate_ch & Change in mortgage rates (FRM30, FRM15 and ARM rates) from origination. Source: Freddie Mac PMM \\
& Survey. \\
mcltv & Mark to market cltv: mcltv = current UPB / current home value; current home value = origination home value * \\
obs & hp appreciation.
\end{tabular} \\
\hline
\end{tabular}


Confidential - Internal Distribution 
Table 2

Descriptive Statistics

\begin{tabular}{|c|c|c|c|c|c|c|c|c|}
\hline \multirow[b]{2}{*}{ Variable } & \multirow[b]{2}{*}{ All } & \multicolumn{3}{|c|}{ Status } & \multicolumn{4}{|c|}{ Vintage Year } \\
\hline & & Defaulted & Prepaid & Other & 2005 & 2006 & 2007 & 2008 \\
\hline \multirow[t]{2}{*}{ duration } & 9.47 & 8.55 & 7.56 & 10.09 & 14.32 & 11.03 & 7.95 & 4.53 \\
\hline & $(4.25)$ & $(3.26)$ & $(3.86)$ & $(4.20)$ & $(4.09)$ & $(2.81)$ & (1.69) & $(1.15)$ \\
\hline \multirow[t]{2}{*}{ default } & $1.6 \%$ & $100 \%$ & $0.0 \%$ & $0.0 \%$ & $1.8 \%$ & $2.4 \%$ & $1.8 \%$ & $0.2 \%$ \\
\hline & $(12.7 \%)$ & $(0.0 \%)$ & $(0.0 \%)$ & $(0.0 \%)$ & $(13.2 \%)$ & $(15.2 \%)$ & $(13.3 \%)$ & $(4.6 \%)$ \\
\hline \multirow[t]{2}{*}{ prepay } & $23.6 \%$ & $0.0 \%$ & $100 \%$ & $0.0 \%$ & $28.9 \%$ & $29.8 \%$ & $20.0 \%$ & $15.6 \%$ \\
\hline & $(42.5 \%)$ & $(0.0 \%)$ & $(0.0 \%)$ & $(0.0 \%)$ & $(45.3 \%)$ & $(45.7 \%)$ & $(40.0 \%)$ & $(36.3 \%)$ \\
\hline \multirow[t]{2}{*}{ cltv } & 86.10 & 97.20 & 81.90 & 87.20 & 84.60 & 86.80 & 88.50 & 82.70 \\
\hline & $(15.7)$ & $(6.0)$ & $(17.3)$ & $(15.0)$ & $(16.7)$ & $(16.2)$ & (14.7) & $(14.5)$ \\
\hline \multirow[t]{2}{*}{ broker } & $22.6 \%$ & $35.9 \%$ & $20.9 \%$ & $22.8 \%$ & $20.3 \%$ & $22.1 \%$ & $24.8 \%$ & $22.0 \%$ \\
\hline & $(41.8 \%)$ & $(48.0 \%)$ & $(40.7 \%)$ & $(42.0 \%)$ & $(40.2 \%)$ & $(41.5 \%)$ & $(43.2 \%)$ & $(41.5 \%)$ \\
\hline \multirow[t]{2}{*}{ correspondent } & $33.1 \%$ & $37.7 \%$ & $35.1 \%$ & $32.4 \%$ & $27.7 \%$ & $34.4 \%$ & $38.1 \%$ & $28.8 \%$ \\
\hline & $(47.1 \%)$ & $(48.5 \%)$ & $(47.7 \%)$ & $(46.8 \%)$ & $(44.7 \%)$ & $(47.5 \%)$ & $(48.6 \%)$ & $(45.3 \%)$ \\
\hline \multirow[t]{2}{*}{ fico } & 718.8 & 655.7 & 731.9 & 716 & 717.1 & 713.7 & 711.6 & 739.9 \\
\hline & $(61.8)$ & $(62.3)$ & $(58.9)$ & $(61.4)$ & $(61.1)$ & $(62.8)$ & $(64.2)$ & $(51.2)$ \\
\hline \multirow[t]{2}{*}{ age } & 39.5 & 37.1 & 40.2 & 39.3 & 39.9 & 39.2 & 39 & 40.3 \\
\hline & (12.4) & $(12.4)$ & (12.6) & (12.3) & (12.8) & $(12.6)$ & (12.1) & $(12.2)$ \\
\hline \multirow[t]{2}{*}{ income } & $\$ 6,900$ & $\$ 5,320$ & $\$ 7,634$ & $\$ 6,702$ & $\$ 6,252$ & $\$ 6,648$ & $\$ 6,887$ & $\$ 7,995$ \\
\hline & $(\$ 4,727)$ & $(\$ 3,319)$ & $(\$ 5,149)$ & $(\$ 4,584)$ & $(\$ 3,930)$ & $(\$ 4,453)$ & $(\$ 4,566)$ & $(\$ 5,868)$ \\
\hline \multirow[t]{2}{*}{ y2005 } & $22 \%$ & $23 \%$ & $27 \%$ & $20 \%$ & $100 \%$ & $0 \%$ & $0 \%$ & $0 \%$ \\
\hline & $(0.41)$ & $(0.42)$ & $(0.44)$ & $(0.40)$ & $(0.00)$ & $(0.00)$ & $(0.00)$ & $(0.00)$ \\
\hline \multirow[t]{2}{*}{ y2006 } & $26 \%$ & $37 \%$ & $32 \%$ & $23 \%$ & $0 \%$ & $100 \%$ & $0 \%$ & $0 \%$ \\
\hline & $(0.44)$ & $(0.48)$ & $(0.47)$ & $(0.42)$ & $(0.00)$ & $(0.00)$ & $(0.00)$ & $(0.00)$ \\
\hline \multirow[t]{2}{*}{ y2007 } & $34 \%$ & $37 \%$ & $28 \%$ & $35 \%$ & $0 \%$ & $0 \%$ & $100 \%$ & $0 \%$ \\
\hline & $(0.47)$ & $(0.48)$ & $(0.45)$ & $(0.48)$ & $(0.00)$ & $(0.00)$ & $(0.00)$ & $(0.00)$ \\
\hline \multirow[t]{2}{*}{ y2008 } & $19 \%$ & $2 \%$ & $13 \%$ & $22 \%$ & $0 \%$ & $0 \%$ & $0 \%$ & $100 \%$ \\
\hline & $(0.39)$ & $(0.16)$ & $(0.33)$ & $(0.41)$ & $(0.00)$ & $(0.00)$ & $(0.00)$ & $(0.00)$ \\
\hline obs & 694,951 & 11,366 & 164,063 & 519,522 & 150,930 & 178,064 & 233,132 & 132,825 \\
\hline$\%$ obs & $100 \%$ & $1.6 \%$ & $23.6 \%$ & $74.8 \%$ & $22 \%$ & $26 \%$ & $34 \%$ & $19 \%$ \\
\hline \multicolumn{9}{|l|}{ At Termination } \\
\hline \multirow[t]{2}{*}{ mcltv } & 90.6 & 111.4 & 78.7 & 94 & 82 & 91.4 & 97.6 & 87.1 \\
\hline & $(27.0)$ & $(30.3)$ & $(18.6)$ & $(28.0)$ & $(24.4)$ & $(28.6)$ & $(29.0)$ & (19.8) \\
\hline \multirow[t]{2}{*}{ msaemp_ch } & $3.5 \%$ & $2.2 \%$ & $1.7 \%$ & $4.1 \%$ & $2.9 \%$ & $3.5 \%$ & $4.0 \%$ & $3.3 \%$ \\
\hline & $(2.2 \%)$ & $(2.3 \%)$ & $(2.1 \%)$ & $(1.8 \%)$ & $(2.6 \%)$ & $(2.4 \%)$ & $(1.9 \%)$ & $(1.4 \%)$ \\
\hline \multirow[t]{2}{*}{ rate_ch } & -1.00 & -0.47 & -0.56 & -1.15 & -0.52 & -1.15 & -1.21 & -0.99 \\
\hline & $(0.5)$ & $(0.6)$ & $(0.7)$ & $(0.3)$ & $(0.6)$ & $(0.5)$ & $(0.3)$ & $(0.2)$ \\
\hline
\end{tabular}

Numbers in the parenthesis are standard deviation.

Confidential - Internal Distribution 
Table 3

Distribution of MCLTV by CLTV

\begin{tabular}{rrrrrr}
\hline \multirow{2}{*}{ MCLTV } & \multicolumn{5}{c}{ CLTV } \\
\cline { 2 - 5 }$<=80$ & 29.8 & 2 & 0.9 & 0.7 & 33.4 \\
$(80,90]$ & 5.4 & 7.4 & 3.5 & 3.2 & 19.6 \\
$(90,95]$ & 0.7 & 2.2 & 5.6 & 5.5 & 14 \\
$(95,100]$ & 0.4 & 0.8 & 2.6 & 12.3 & 16.1 \\
$(100,110]$ & 0.6 & 0.6 & 1.3 & 7.9 & 10.4 \\
$(110,120]$ & 0.3 & 0.3 & 0.5 & 1.5 & 2.6 \\
$(120,130]$ & 0.2 & 0.2 & 0.3 & 0.7 & 1.3 \\
$(130,140]$ & 0.1 & 0.1 & 0.2 & 0.4 & 0.8 \\
$(140,150]$ & 0.1 & 0.1 & 0.1 & 0.3 & 0.6 \\
$>150$ & 0.1 & 0.1 & 0.2 & 0.7 & 1.1 \\
\cline { 2 - 5 } Total & 37.7 & 13.8 & 15.2 & 33.3 & 100 \\
\hline
\end{tabular}

Confidential - Internal Distribution 
Table 4 Competing Risk Model

(A)

Estimates from Hazard Model

\begin{tabular}{|c|c|c|c|c|}
\hline & \multicolumn{2}{|c|}{ Default } & \multicolumn{2}{|c|}{ Prepay } \\
\hline Obs Used & $5,990,234$ & & $6,142,773$ & \\
\hline LR & $31,055^{* * *}$ & & $191,256^{* * *}$ & \\
\hline Score & $30,935 * * *$ & & $191,136 * * *$ & \\
\hline Wald & $30,494 * * *$ & & $190,535 * * *$ & \\
\hline Variable & Coef & Hazard Ratio & Coef & Hazard Ratio \\
\hline$(25,35]$ & $-0.220 * * *$ & 0.802 & $-0.027 * * *$ & 0.974 \\
\hline$(35,45]$ & $-0.073 * *$ & 0.929 & $-0.083 * * *$ & 0.92 \\
\hline$(45,55]$ & $-0.115^{* * *}$ & 0.891 & $-0.169 * * *$ & 0.844 \\
\hline$(55,65]$ & $0.132 * * *$ & 1.142 & $-0.130 * * *$ & 0.878 \\
\hline$>65$ & $0.526 * * *$ & 1.692 & $0.078 * * *$ & 1.081 \\
\hline Broker & $0.709 * * *$ & 2.031 & $0.082 * * *$ & 1.085 \\
\hline Correpondent & $0.490 * * *$ & 1.632 & $0.084 * * *$ & 1.087 \\
\hline$\overline{\text { FICO }(620,660]}$ & $-0.656 * * *$ & 0.519 & $-0.071 * * *$ & 0.931 \\
\hline$(660,700]$ & $-1.021 * * *$ & 0.36 & 0.001 & 1.001 \\
\hline$(700,740]$ & $-1.372 * * *$ & 0.254 & $0.087 * * *$ & 1.091 \\
\hline$>740$ & $-2.038 * * *$ & 0.13 & $0.281 * * *$ & 1.324 \\
\hline Income $(\$ 2 \mathrm{k}, \$ 4 \mathrm{k}]$ & $-0.386^{* * *}$ & 0.68 & $0.309 * * *$ & 1.362 \\
\hline$(\$ 4 \mathrm{k}, \$ 6 \mathrm{k}]$ & $-0.529 * * *$ & 0.589 & $0.520 * * *$ & 1.682 \\
\hline$(\$ 6 \mathrm{k}, \$ 8 \mathrm{k}]$ & $-0.584 * * *$ & 0.558 & $0.653 * * *$ & 1.921 \\
\hline$(\$ 8 \mathrm{k}, \$ 10 \mathrm{k}]$ & $-0.598 * * *$ & 0.55 & $0.729 * * *$ & 2.072 \\
\hline$>\$ 10 \mathrm{k}$ & $-0.538 * * *$ & 0.584 & $0.879 * * *$ & 2.409 \\
\hline msaemp_ch & $-14.479 * * *$ & & $-18.191 * * *$ & \\
\hline rate_ch & $0.839 * * *$ & & $-0.165 * * *$ & \\
\hline y2006 & $1.966 * * *$ & 7.143 & $1.463 * * *$ & 4.318 \\
\hline y2007 & $3.211 * * *$ & 24.797 & $2.646^{* * *}$ & 14.093 \\
\hline y2008 & $4.202 * * *$ & 66.787 & $4.113 * * *$ & 61.121 \\
\hline mcltv*cltv & & in table below & & \\
\hline
\end{tabular}

(B)

Confidential - Internal Distribution 
Estimated Coefficients on MCLTV by CLTV from Hazard Model

\begin{tabular}{|c|c|c|c|c|c|c|c|c|}
\hline & \multicolumn{4}{|c|}{ Default } & \multicolumn{4}{|c|}{ Prepay } \\
\hline & $<=80$ & $(80,90]$ & $(90,95]$ & $(95,100]$ & $<=80$ & $(80,90]$ & $(90,95]$ & $(95,100]$ \\
\hline$<=80$ & 0 & 0.21 & 0.15 & 0.83 & 0 & -0.29 & -0.18 & 0.06 \\
\hline$(80,90]$ & 1.08 & 1.33 & 1.29 & 1.65 & -0.28 & -0.17 & -0.3 & -0.27 \\
\hline$(90,95]$ & 1.2 & 1.67 & 2.07 & 2.35 & -0.82 & -0.48 & -0.32 & -0.46 \\
\hline$(95,100]$ & 1.68 & 1.98 & 2.33 & 2.71 & -1.09 & -1 & -0.75 & -0.57 \\
\hline$(100,110]$ & 1.76 & 2.51 & 2.65 & 2.91 & -1.44 & -1.43 & -1.31 & -1.04 \\
\hline$(110,120]$ & 2.09 & 2.88 & 2.81 & 3.18 & -1.95 & -2.04 & -1.87 & -1.79 \\
\hline$(120,130]$ & 2.4 & 3.03 & 3.18 & 3.35 & -2.52 & -2.53 & -2.41 & -2.4 \\
\hline$(130,140]$ & 2.9 & 3.22 & 3.24 & 3.36 & -2.51 & -3.11 & -3.24 & -3.07 \\
\hline$(140,150]$ & 2.66 & 2.92 & 3.56 & 3.62 & -3.03 & -3.56 & -3.19 & -3.08 \\
\hline$>150$ & 3.08 & 3.57 & 3.93 & 4.04 & -3.85 & -4.33 & -4.3 & -4.17 \\
\hline
\end{tabular}

Note: Columns are CLTV; rows are MCLTV. 
Table 5 Robustness Check based on Restricted Samples

Coefficients on MCLTV by CLTV from Hazard Model: Restricted Samples

\begin{tabular}{|c|c|c|c|c|c|c|c|c|}
\hline & \multicolumn{8}{|c|}{ Subsample: MCLTV > 95 } \\
\hline & \multicolumn{4}{|c|}{ Default } & \multicolumn{4}{|c|}{ Prepayment } \\
\hline & \multicolumn{4}{|c|}{$<=80 \quad(80,90] \quad(90,95] \quad(95,100]$} & \multicolumn{4}{|c|}{$<=80 \quad(80,90] \quad(90,95] \quad(95,100]$} \\
\hline $\begin{array}{r}<=80 \\
(80,90] \\
(90,95]\end{array}$ & & & & & & & & \\
\hline$(95,100]$ & 0.00 & 1.97 & 2.35 & 2.80 & 0.00 & -0.93 & -0.69 & -0.62 \\
\hline$(100,110]$ & 1.76 & 2.51 & 2.66 & 3.00 & -1.44 & -1.35 & -1.24 & -1.03 \\
\hline$(110,120]$ & 2.09 & 2.89 & 2.83 & 3.25 & -1.92 & -1.96 & -1.80 & -1.76 \\
\hline$(120,130]$ & 2.41 & 3.03 & 3.19 & 3.42 & -2.47 & -2.44 & -2.31 & -2.36 \\
\hline$(130,140]$ & 2.90 & 3.23 & 3.26 & 3.43 & -2.44 & -3.01 & -3.12 & -3.01 \\
\hline$(140,150]$ & 2.67 & 2.92 & 3.57 & 3.68 & -2.93 & -3.44 & -3.06 & -3.00 \\
\hline \multirow[t]{4}{*}{$>150$} & 3.09 & 3.57 & 3.94 & 4.09 & -3.69 & -4.15 & -4.10 & -4.01 \\
\hline & \multicolumn{8}{|c|}{ Subsample: CLTV >95 } \\
\hline & \multicolumn{4}{|c|}{ Default } & \multicolumn{4}{|c|}{ Prepayment } \\
\hline & \multicolumn{4}{|c|}{$<=80 \quad(80,90] \quad(90,95] \quad(95,100]$} & \multicolumn{3}{|c|}{$<=80 \quad(80,90] \quad(90,95]$} & $(95,100]$ \\
\hline$<=80$ & & & & 0.83 & & & & 0.06 \\
\hline$(80,90]$ & & & & 1.66 & & & & -0.11 \\
\hline$(90,95]$ & & & & 2.37 & & & & -0.08 \\
\hline$(95,100]$ & & & & 2.76 & & & & -0.02 \\
\hline$(100,110]$ & & & & 2.97 & & & & -0.44 \\
\hline$(110,120]$ & & & & 3.23 & & & & -1.19 \\
\hline$(120,130]$ & & & & 3.40 & & & & -1.81 \\
\hline$(130,140]$ & & & & 3.42 & & & & -2.47 \\
\hline$(140,150]$ & & & & 3.67 & & & & -2.47 \\
\hline$>150$ & & & & 4.11 & & & & -3.45 \\
\hline
\end{tabular}

Confidential - Internal Distribution 
Table 6

Descriptive Statistics by States

\begin{tabular}{|c|c|c|c|c|c|c|c|c|c|c|c|c|}
\hline \multirow[b]{2}{*}{ Variable } & \multicolumn{4}{|c|}{$\mathrm{CA}$} & \multicolumn{4}{|c|}{ FL } & \multicolumn{4}{|c|}{$\mathrm{TX}$} \\
\hline & All & Defaulted & id & Other & All & faulted & & Other & All & aulted & & ther \\
\hline duration & $\begin{array}{c}7.31 \\
(4.10)\end{array}$ & $\begin{array}{c}8.31 \\
(3.10)\end{array}$ & $\begin{array}{c}5.56 \\
(3.48)\end{array}$ & $\begin{array}{c}7.66 \\
(4.15)\end{array}$ & $\begin{array}{l}10.18 \\
(4.34)\end{array}$ & & $\begin{array}{c}6.95 \\
(3.67)\end{array}$ & $\begin{array}{l}10.72 \\
(4.23)\end{array}$ & $\begin{array}{c}9.54 \\
(4.02)\end{array}$ & $\begin{array}{c}7.77 \\
(2.98)\end{array}$ & $\begin{array}{c}0.25 \\
(3.70)\end{array}$ & $\begin{array}{c}9.88 \\
(4.03)\end{array}$ \\
\hline de & $\begin{array}{c}1.9 \% \\
(13.5 \%)\end{array}$ & $\begin{array}{l}100 \% \\
(0.0 \%)\end{array}$ & $\begin{array}{c}0.0 \% \\
(0.0 \%)\end{array}$ & $\begin{array}{c}0.0 \% \\
(0.0 \%)\end{array}$ & $\begin{array}{c}1.9 \% \\
(13.7 \%)\end{array}$ & & & & $\begin{array}{c}1.4 \% \\
(11.8 \%)\end{array}$ & & & \\
\hline prep & $\begin{array}{c}16.9 \% \\
(37.5 \%)\end{array}$ & $\begin{array}{c}0.0 \% \\
(0.0 \%)\end{array}$ & $\begin{array}{l}100 \% \\
(0.0 \%)\end{array}$ & $\begin{array}{c}0.0 \% \\
(0.0 \%)\end{array}$ & $\begin{array}{c}14.1 \% \\
(34.8 \%)\end{array}$ & $\begin{array}{c}0.0 \% \\
(0.0 \%)\end{array}$ & $\begin{array}{l}100 \% \\
(0.0 \%)\end{array}$ & $\begin{array}{c}0.0 \% \\
(0.0 \%)\end{array}$ & $\begin{array}{c}18.6 \% \\
(38.9 \%)\end{array}$ & & & $\begin{array}{c}0.0 \% \\
(0.0 \%)\end{array}$ \\
\hline cltv & & & & $\begin{array}{l}80.90 \\
(16.7)\end{array}$ & & & & & & & & \\
\hline broker & $\begin{array}{c}33.3 \% \\
(47.1 \%)\end{array}$ & $\begin{array}{l}44 . \\
(49 .\end{array}$ & $\begin{array}{c}34.2 \% \\
(47.4 \%)\end{array}$ & $\begin{array}{c}32.9 \% \\
(47.0 \%)\end{array}$ & $\begin{array}{c}28.1 \% \\
(44.9 \%)\end{array}$ & $\begin{array}{c}40.6 \% \\
(49.1 \%)\end{array}$ & $\begin{array}{r}24 . \\
(42 .\end{array}$ & $\begin{array}{r}28 . \\
(45 .\end{array}$ & $\begin{array}{r}22 . \\
(41 .\end{array}$ & $\begin{array}{r}32 \\
(46\end{array}$ & $\begin{array}{r}19 \\
(39\end{array}$ & $\begin{array}{r}22 \\
(41\end{array}$ \\
\hline correspondent & $\begin{array}{c}32.8 \% \\
(46.9 \%)\end{array}$ & $\begin{array}{c}37.9 \% \\
(48.5 \%)\end{array}$ & $\begin{array}{c}30.4 \% \\
(46.0 \%)\end{array}$ & $\begin{array}{c}33.1 \% \\
(47.1 \%)\end{array}$ & $\begin{array}{c}23.9 \% \\
(42.7 \%)\end{array}$ & $\begin{array}{c}26.8 \% \\
(44.3 \%)\end{array}$ & $\begin{array}{c}23.8 \% \\
(42.6 \%)\end{array}$ & $\begin{array}{c}23.9 \% \\
(42.6 \%)\end{array}$ & $\begin{array}{c}40.9 \% \\
(49.2 \%)\end{array}$ & & & \\
\hline fico & $\begin{array}{l}736.5 \\
(50.9)\end{array}$ & $\begin{array}{l}695.5 \\
(47.7)\end{array}$ & & $\begin{array}{l}734.2 \\
(50.6)\end{array}$ & $\begin{array}{l}713.4 \\
(61.2)\end{array}$ & & & & & & $\begin{array}{c}728 \\
(58.6)\end{array}$ & \\
\hline age & $\begin{array}{c}42.1 \\
(12.5)\end{array}$ & $\begin{array}{c}38.8 \\
(12.1)\end{array}$ & $\begin{array}{c}44.2 \\
(12.9)\end{array}$ & $\begin{array}{c}41.7 \\
(12.4)\end{array}$ & $\begin{array}{c}41.7 \\
(13.2)\end{array}$ & $\begin{array}{c}38.1 \\
(12.1)\end{array}$ & $\begin{array}{c}44 \\
(14.1)\end{array}$ & & $\begin{array}{c}39.9 \\
(12.2)\end{array}$ & $\begin{array}{c}37.5 \\
(12.5)\end{array}$ & $\begin{array}{c}40.7 \\
(12.6)\end{array}$ & $\begin{array}{c}39.8 \\
(12.1)\end{array}$ \\
\hline income & $\begin{array}{c}\$ 8,851 \\
(\$ 5,660)\end{array}$ & $\begin{array}{c}\$ 8,279 \\
(\$ 3,034)\end{array}$ & $\begin{array}{c}\$ 9,944 \\
(\$ 6,135)\end{array}$ & $\begin{array}{c}\$ 8,637 \\
(\$ 5,576)\end{array}$ & $\begin{array}{c}\$ 6,916 \\
(\$ 4,827)\end{array}$ & $\begin{array}{c}\$ 6,313 \\
(\$ 3,320)\end{array}$ & $\begin{array}{c}\$ 7,115 \\
(\$ 5,103)\end{array}$ & $\begin{array}{c}\$ 6,896 \\
(\$ 4,806)\end{array}$ & $\begin{array}{c}\$ 7,249 \\
(\$ 5,027)\end{array}$ & $\begin{array}{c}\$ 5,835 \\
(\$ 4,197)\end{array}$ & $\begin{array}{c}\$ 8,494 \\
(\$ 5,874)\end{array}$ & $\begin{array}{c}\$ 6,984 \\
(\$ 4,775)\end{array}$ \\
\hline y2005 & $\begin{array}{c}0.12 \\
(0.32)\end{array}$ & & $\begin{array}{c}20 \% \\
(0.40)\end{array}$ & $\begin{array}{c}10 \% \\
(0.30)\end{array}$ & $\begin{array}{c}0.28 \\
(0.45)\end{array}$ & $\begin{array}{c}29 \% \\
(0.46)\end{array}$ & & & $\begin{array}{c}0.19 \\
(0.39)\end{array}$ & & & $\begin{array}{c}17 \% \\
(0.38)\end{array}$ \\
\hline y2006 & $\begin{array}{c}0.14 \\
(0.34)\end{array}$ & $\begin{array}{c}33 \% \\
(0.47)\end{array}$ & $\begin{array}{c}19 \% \\
(0.40)\end{array}$ & $\begin{array}{c}12 \% \\
(0.33)\end{array}$ & $\begin{array}{c}0.26 \\
(0.44)\end{array}$ & $\begin{array}{l}45 \% \\
(0.50)\end{array}$ & $\begin{array}{c}27 \% \\
(0.44)\end{array}$ & $\begin{array}{c}25 \% \\
(0.43)\end{array}$ & $\begin{array}{c}0.26 \\
(0.44)\end{array}$ & $\begin{array}{l}35 \% \\
(0.48)\end{array}$ & $\begin{array}{c}35 \% \\
(0.48)\end{array}$ & $\begin{array}{c}23 \% \\
(0.42)\end{array}$ \\
\hline$y^{2}$ & $\begin{array}{c}0.28 \\
(0.45)\end{array}$ & $\begin{array}{l}48 \% \\
(0.50)\end{array}$ & $\begin{array}{l}23 \% \\
(0.42)\end{array}$ & $\begin{array}{c}29 \% \\
(0.45)\end{array}$ & $\begin{array}{c}0.31 \\
(0.46)\end{array}$ & $\begin{array}{c}25 \% \\
(0.43)\end{array}$ & $\begin{array}{c}16 \% \\
(0.37)\end{array}$ & $\begin{array}{c}34 \% \\
(0.47)\end{array}$ & $\begin{array}{c}0.36 \\
(0.48)\end{array}$ & $\begin{array}{l}41 \% \\
(0.49)\end{array}$ & $\begin{array}{c}29 \% \\
(0.46)\end{array}$ & $\begin{array}{c}38 \% \\
(0.48)\end{array}$ \\
\hline y2008 & & $\begin{array}{c}5 \% \\
(0.22)\end{array}$ & $\begin{array}{c}38 \% \\
(0.49)\end{array}$ & $\begin{array}{c}49 \% \\
(0.50)\end{array}$ & $\begin{array}{c}0.15 \\
(0.36)\end{array}$ & $\begin{array}{c}1 \% \\
(0.08)\end{array}$ & $\begin{array}{c}7 \% \\
(0.25)\end{array}$ & $\begin{array}{c}17 \% \\
(0.37)\end{array}$ & $\begin{array}{c}0.19 \\
(0.40)\end{array}$ & $\begin{array}{c}3 \% \\
(0.17)\end{array}$ & & $\begin{array}{c}22 \% \\
(0.41)\end{array}$ \\
\hline$\%$ obs & $\begin{array}{c}43,272 \\
100 \% \\
\end{array}$ & & & & $\begin{array}{c}50,369 \\
100 \% \\
\end{array}$ & & & & $\begin{array}{c}72,956 \\
100 \% \\
\end{array}$ & & & $\begin{array}{l}58,387 \\
80.0 \% \\
\end{array}$ \\
\hline & & & & & & & & & & & & \\
\hline mcltv & $\begin{array}{l}108.2 \\
(42.9)\end{array}$ & $\begin{array}{l}152.1 \\
(38.0)\end{array}$ & $\begin{array}{c}73.1 \\
(22.2)\end{array}$ & $\begin{array}{l}114.5 \\
(42.3)\end{array}$ & $\begin{array}{l}115.5 \\
(39.3)\end{array}$ & $\begin{array}{l}138.3 \\
(37.8)\end{array}$ & $\begin{array}{c}78.8 \\
(23.6)\end{array}$ & $\begin{array}{l}121.1 \\
(38.0)\end{array}$ & $\begin{array}{c}83.1 \\
(15.3)\end{array}$ & $\begin{array}{l}94.5 \\
(7.7)\end{array}$ & $\begin{array}{c}78.6 \\
(17.0)\end{array}$ & $\begin{array}{c}84 \\
(14.7)\end{array}$ \\
\hline msaen & $\begin{array}{c}4.8 \% \\
(2.2 \%)\end{array}$ & $\begin{array}{c}4.1 \% \\
(2.5 \%)\end{array}$ & $\begin{array}{c}2.6 \% \\
(2.4 \%)\end{array}$ & $\begin{array}{c}5.3 \% \\
(1.8 \%)\end{array}$ & $\begin{array}{c}5.4 \% \\
(2.3 \%)\end{array}$ & $\begin{array}{c}4.4 \% \\
(2.5 \%)\end{array}$ & $\begin{array}{c}1.7 \% \\
(2.4 \%)\end{array}$ & $\begin{array}{c}6.1 \% \\
(1.5 \%)\end{array}$ & $\begin{array}{c}2.0 \% \\
(1.0 \%)\end{array}$ & $\begin{array}{c}0.6 \% \\
(1.3 \%)\end{array}$ & $\begin{array}{c}0.9 \% \\
(1.4 \%)\end{array}$ & $\begin{array}{c}2.3 \% \\
(0.7 \%)\end{array}$ \\
\hline ra & $\begin{array}{r}-1.02 \\
(0.4)\end{array}$ & $\begin{array}{c}-0.58 \\
(0.6)\end{array}$ & $\begin{array}{l}-0.61 \\
(0.6)\end{array}$ & $\begin{array}{r}-1.12 \\
(0.3)\end{array}$ & $\begin{array}{c}-0.99 \\
(0.5)\end{array}$ & $\begin{array}{c}-0.56 \\
(0.7)\end{array}$ & $\begin{array}{c}-0.12 \\
(0.7)\end{array}$ & $\begin{array}{r}-1.15 \\
(0.3)\end{array}$ & $\begin{array}{r}-1.06 \\
(0.5)\end{array}$ & $\begin{array}{r}-0.41 \\
(0.6)\end{array}$ & $\begin{array}{l}-0.61 \\
(0.7)\end{array}$ & $\begin{array}{r}-1.17 \\
(0.3)\end{array}$ \\
\hline
\end{tabular}

Numbers in the parenthesis are standard deviation.

Confidential - Internal Distribution 
Table 7

Coefficients on MCLTV by CLTV from Hazard Model (default): by state

\begin{tabular}{|c|c|c|c|c|c|c|c|c|}
\hline & \multicolumn{4}{|c|}{ US } & \multicolumn{4}{|c|}{ CA } \\
\hline & $<=80$ & $(80,90]$ & $(90,95]$ & $(95,100]$ & $<=80$ & $(80,90]$ & $(90,95]$ & $(95,100]$ \\
\hline$<=80$ & 0.00 & 0.21 & 0.15 & 0.83 & 0.00 & 1.75 & -10.12 & -10.46 \\
\hline$(80,90]$ & 1.08 & 1.33 & 1.29 & 1.65 & 1.75 & 2.24 & 3.63 & -10.27 \\
\hline$(90,95]$ & 1.20 & 1.67 & 2.07 & 2.35 & 1.98 & 3.38 & 2.75 & 4.40 \\
\hline$(95,100]$ & 1.68 & 1.98 & 2.33 & 2.71 & 2.65 & 3.05 & 3.34 & 3.91 \\
\hline$(100,110]$ & 1.76 & 2.51 & 2.65 & 2.91 & 2.28 & 3.27 & 3.46 & 4.64 \\
\hline$(110,120]$ & 2.09 & 2.88 & 2.81 & 3.18 & 3.26 & 4.06 & 3.96 & 5.00 \\
\hline$(120,130]$ & 2.40 & 3.03 & 3.18 & 3.35 & 3.79 & 4.33 & 4.83 & 5.40 \\
\hline$(130,140]$ & 2.90 & 3.22 & 3.24 & 3.36 & 3.83 & 4.29 & 4.47 & 5.05 \\
\hline$(140,150]$ & 2.66 & 2.92 & 3.56 & 3.62 & 3.87 & 4.17 & 5.20 & 5.53 \\
\hline \multirow[t]{3}{*}{$>150$} & 3.08 & 3.57 & 3.93 & 4.04 & 4.01 & 4.92 & 5.56 & 5.86 \\
\hline & \multicolumn{4}{|c|}{ FL } & \multicolumn{4}{|c|}{ TX } \\
\hline & $<=80$ & $(80,90]$ & $(90,95]$ & $(95,100]$ & $<=80$ & $(80,90]$ & $(90,95]$ & $(95,100]$ \\
\hline$<=80$ & 0.00 & 0.89 & -9.91 & 1.94 & 0.00 & 0.18 & -0.15 & -0.21 \\
\hline$(80,90]$ & 1.41 & 1.50 & 1.62 & 2.45 & 1.81 & 1.42 & 1.20 & 1.33 \\
\hline$(90,95]$ & 1.29 & 1.70 & 1.96 & 2.73 & 3.36 & 2.84 & 2.55 & 2.17 \\
\hline$(95,100]$ & 2.12 & -9.46 & 1.95 & 2.95 & -8.42 & -7.50 & 2.97 & 2.98 \\
\hline$(100,110]$ & 2.35 & 2.92 & 2.33 & 3.28 & -7.65 & -7.51 & 3.29 & 3.11 \\
\hline$(110,120]$ & 2.27 & 2.80 & 2.91 & 3.45 & - & -8.61 & -7.67 & 3.29 \\
\hline$(120,130]$ & 2.49 & 3.41 & 3.31 & 4.12 & - & - & -7.58 & 3.75 \\
\hline$(130,140]$ & 3.62 & 3.77 & 3.60 & 4.06 & - & - & - & -8.37 \\
\hline$(140,150]$ & 3.08 & 3.39 & 3.95 & 4.12 & - & - & - & - \\
\hline$>150$ & 4.01 & 4.12 & 4.14 & 4.56 & - & - & - & - \\
\hline
\end{tabular}

Numbers in bold are statistically significant (p-value $<=10 \%$ ).

Confidential - Internal Distribution 
Table 8

Coefficients on MCLTV by CLTV from Hazard Model (prepayment): by state

\begin{tabular}{|c|c|c|c|c|c|c|c|c|}
\hline & \multicolumn{4}{|c|}{ US } & \multicolumn{4}{|c|}{$\mathrm{CA}$} \\
\hline & $<=80$ & $(80,90]$ & $(90,95]$ & $(95,100]$ & $<=80$ & $(80,90]$ & $(90,95]$ & $(95,100]$ \\
\hline$<=80$ & 0.00 & -0.29 & -0.18 & 0.06 & 0.00 & 0.33 & 0.34 & 0.35 \\
\hline$(80,90]$ & -0.28 & -0.17 & -0.30 & -0.27 & -0.26 & 0.01 & 0.56 & 1.03 \\
\hline$(90,95]$ & -0.82 & -0.48 & -0.32 & -0.46 & -0.91 & -0.38 & 0.22 & 0.61 \\
\hline$(95,100]$ & -1.09 & -1.00 & -0.75 & -0.57 & -1.34 & -0.94 & -0.64 & 0.26 \\
\hline$(100,110]$ & -1.44 & -1.43 & -1.31 & -1.04 & -1.83 & -1.50 & -1.27 & -0.80 \\
\hline$(110,120]$ & -1.95 & -2.04 & -1.87 & -1.79 & -2.40 & -2.40 & -2.19 & -1.88 \\
\hline$(120,130]$ & -2.52 & -2.53 & -2.41 & -2.40 & -2.93 & -3.25 & -2.74 & -2.45 \\
\hline$(130,140]$ & -2.51 & -3.11 & -3.24 & -3.07 & -3.20 & -3.48 & -3.98 & -3.61 \\
\hline$(140,150]$ & -3.03 & -3.56 & -3.19 & -3.08 & -3.13 & -13.20 & -13.14 & -3.99 \\
\hline \multirow[t]{3}{*}{$>150$} & -3.85 & -4.33 & -4.30 & -4.17 & -4.85 & -4.51 & -4.47 & -5.14 \\
\hline & \multicolumn{4}{|c|}{ FL } & \multicolumn{4}{|c|}{$\mathrm{TX}$} \\
\hline & $<=80$ & $(80,90]$ & $(90,95]$ & $(95,100]$ & $<=80$ & $(80,90]$ & $(90,95]$ & $(95,100]$ \\
\hline$<=80^{\circ}$ & 0.00 & 0.15 & 0.29 & 0.65 & 0.00 & -0.60 & -0.51 & -0.33 \\
\hline$(80,90]$ & -0.29 & -0.03 & 0.35 & 0.45 & 0.56 & 0.11 & -0.35 & -0.60 \\
\hline$(90,95]$ & -0.59 & -0.42 & 0.06 & 0.17 & -8.97 & 0.24 & 0.25 & -0.39 \\
\hline$(95,100]$ & -0.46 & -0.56 & -0.65 & -0.22 & -9.08 & -1.20 & -0.06 & -0.12 \\
\hline$(100,110]$ & -0.73 & -1.02 & -0.98 & -0.93 & -8.70 & -9.14 & -0.49 & -0.44 \\
\hline$(110,120]$ & -1.24 & -1.31 & -1.27 & -1.57 & - & -9.29 & -9.03 & -1.65 \\
\hline$(120,130]$ & -2.01 & -1.74 & -1.69 & -2.13 & - & - & -9.13 & -0.77 \\
\hline$(130,140]$ & -1.90 & -2.42 & -2.11 & -2.26 & - & - & - & -9.20 \\
\hline$(140,150]$ & -2.07 & -2.52 & -1.87 & -2.16 & - & - & - & - \\
\hline$>150$ & -2.58 & -3.39 & -3.67 & -3.44 & - & - & - & - \\
\hline
\end{tabular}

Numbers in bold are statistically significant (p-value $<=10 \%$ ).

Confidential - Internal Distribution 
Table 9

Coefficients on MCLTV by CLTV from Hazard Model (default): by vintage

\begin{tabular}{|c|c|c|c|c|c|c|c|c|}
\hline & \multicolumn{4}{|c|}{2005} & \multicolumn{4}{|c|}{2006} \\
\hline & $<=80$ & $(80,90]$ & $(90,95]$ & $(95,100]$ & $<=80$ & $(80,90]$ & $(90,95]$ & $(95,100]$ \\
\hline$<=80$ & 0.00 & 0.26 & 0.37 & 0.89 & 0.00 & 0.04 & -8.84 & -0.46 \\
\hline$(80,90]$ & 1.21 & 1.47 & 1.42 & 1.65 & 1.15 & 1.14 & 0.91 & 1.45 \\
\hline$(90,95]$ & 1.81 & 1.97 & 2.03 & 2.44 & 0.49 & 1.41 & 1.72 & 2.25 \\
\hline$(95,100]$ & 2.30 & 1.88 & 2.08 & 2.92 & 1.25 & 1.74 & 1.83 & 2.62 \\
\hline$(100,110]$ & 2.34 & 2.52 & 2.44 & 3.06 & 1.46 & 2.37 & 2.20 & 2.84 \\
\hline$(110,120]$ & 2.50 & 2.75 & 2.64 & 3.05 & 1.99 & 2.91 & 2.36 & 3.13 \\
\hline$(120,130]$ & 2.98 & 3.21 & 3.28 & 3.39 & 2.38 & 3.28 & 2.99 & 3.26 \\
\hline$(130,140]$ & 3.43 & 3.04 & 3.38 & 3.47 & 2.56 & 2.62 & 3.45 & 3.51 \\
\hline$(140,150]$ & 2.83 & 3.24 & 3.57 & 3.62 & 3.15 & 3.21 & 3.76 & 4.00 \\
\hline \multirow[t]{3}{*}{$>150$} & 3.40 & 4.23 & 3.68 & 3.91 & 2.65 & 3.27 & 2.70 & 3.15 \\
\hline & \multicolumn{4}{|c|}{2007} & \multicolumn{4}{|c|}{2008} \\
\hline & $<=80$ & $(80,90]$ & $(90,95]$ & $(95,100]$ & $<=80$ & $(80,90]$ & $(90,95]$ & $(95,100]$ \\
\hline$<=80$ & 0.00 & 1.09 & -6.74 & 1.43 & 0.00 & -10.74 & -9.61 & -10.39 \\
\hline$(80,90]$ & 0.86 & 1.44 & 1.67 & 2.21 & 0.62 & 0.81 & 1.22 & -10.36 \\
\hline$(90,95]$ & 0.85 & 79 & 2.37 & 2.17 & 1.55 & .95 & 1.61 & 1.48 \\
\hline$(95,100]$ & 1.53 & 2.08 & 2.68 & 2.72 & 0.46 & 2.06 & 1.97 & 1.33 \\
\hline$(100,110]$ & 1.55 & 2.61 & 3.00 & 2.98 & 0.10 & 2.12 & 2.22 & 1.53 \\
\hline$(110,120]$ & 1.84 & 3.14 & 3.25 & 3.28 & 0.68 & 1.26 & 2.10 & 2.30 \\
\hline$(120,130]$ & 1.62 & 2.44 & 3.36 & 3.43 & -10.37 & 1.69 & 2.13 & 2.53 \\
\hline$(130,140]$ & 2.83 & 3.07 & 3.61 & 3.54 & -10.33 & 2.53 & 2.01 & 1.24 \\
\hline$(140,150]$ & 2.65 & 3.09 & 3.77 & 3.73 & -10.54 & 1.75 & 1.52 & 2.46 \\
\hline$>150$ & 1.81 & 3.35 & 4.11 & 4.07 & 2.68 & 3.23 & 2.67 & 2.61 \\
\hline
\end{tabular}

Numbers in bold are statistically significant ( $\mathrm{p}$-value $<=10 \%$ ).

Confidential - Internal Distribution 